\title{
Keterlaksanaan Program Praktik Industri Program Keahlian Teknik Pemesinan Di SMK Muhammadiyah 1 Kepanjen Menggunakan Evaluasi Model Kirkpatrick
}

\author{
Ahmad Iqbal Ismawanto ${ }^{1}$, Eddy Sutadji ${ }^{2}$, Suharmanto ${ }^{3}$ \\ 1,2,3 Jurusan Teknik Mesin Fakultas Teknik Universitas Negeri Malang \\ e-mail: ${ }^{1}$ ahmadiqba1010697@ gmail.com, ${ }^{2}$ eddy.sutadji.ft@ gmail.com, ${ }^{3}$ suharmantanoum@ gmail.com
}

\begin{abstract}
Abstrak: Tujuan penelitian untuk mengetahui keterlaksanaan program praktik industri menggunakan model evaluasi kirkpatrick yang berfokus pada pengembangan sumber daya manusia. Penelitian ini menggunakan metode evaluasi model kirkpatrick empat level yaitu reaction, learning, behavior, dan result. Subjek penelitian yaitu siswa jurusan teknik pemesinan dan sebagian guru pembimbing praktik industri di SMK Muhammadiyah 1 Kepanjen. Teknik pengumpulan data menggunakan instrumen berupa angket, tes, dan dokumentasi. Berdasarkan analisis data ditemukan bahwa tingkat ketercapaian program praktik industri pada aspek reaction siswa menggunakan indikator fasilitas, materi, instruktur, waktu, dan sarana prasana pada kategori baik. hasil pre-test dan post-test pada aspek learning menunjukkan nilai mean 61,83 nilai mean 80,83, artinya terdapat perubahan signifikan. Aspek behavior berdasarkan penilaian guru menggunakan indikator kecakapan komunikasi, intelektual, strategi kognitif, motorik dan sikap siswa pada kategori baik. Aspek result menunjukkan nilai mean 83,7 (> KKM 75) sehingga memiliki kategori baik.
\end{abstract}

\section{Kata kunci: Evaluasi, Praktik Industri, Kirkpatrick, Keterlaksanaan Program, SMK}

\begin{abstract}
This study aims to observe the implementation of industrial training program using Kirkpatrick evaluation model which focuses on the human source development. This study utilizes the Kirkpatrick fourlevel training evaluation model consisting of reaction, learning, behaviour, and result. The subjects of this study are students of mechanical engineering program and a few of industrial training tutors in SMK Muhammadiyah 1 Kepanjen. This study used questionnaires, tests, and documentations as the instruments. The results shows that in the reaction level, the level of performance of the trained students using indicators such as facilities, material, instructors, time, and infrastructure are within the good category. The results of pre-test and post-test of the learning aspects-with the mean value of 61,83 and mean value of 80,83 - show that there is significant change to the performance. From behaviour level, referring to tutor assessments using indicators such as communication proficiency, intellectuality, cognitive and motoric strategy, as well as student behaviours are also within the good category. Result shows mean value of 83,7 (> Minimum Criteria of Mastery Learning 75) thus resulting in good category.
\end{abstract}

Keywords: Evaluation, Industrial Training, Kirkpatrick, Program Implementation, SMK

Indonesia sebagai salah satu negara berkembang yang memiliki tingkat kepadatan penduduk yang tinggi menjadi salah satu tantangan pemerintah guna menekan angka pengangguran. Jika dilihat dari data BPS tepatnya pada bulan Februari 2018 , BPS mencatat jumlah pengangguran di Indonesia pada Februari 2018 mencapai 6,87 juta orang atau menurun 140.000 dibandingkan periode 2017 sebesar 7,01 juta orang. Tingkat pengangguran terbuka untuk Sekolah Menengah Kejuruan (SMK) tercatat paling tinggi yaitu mencapai $8,92 \%$, [1]. Menghadapi hal tersebut pemerintah Indonesia harus mengoptimalkan peran sekolah khususnya SMK yang menjadi salah satu wadah formal yang secara terencana, terprogram dan sistematis. Untuk itu, SMK perlu memberikan program pelatihan kerja di dunia industri guna membentuk sumber daya manusia yang profesional, produktif, berpotensi dan berkualitas, baik secara hard skill maupun soft skill [2].

Kebijakan pendidikan SMK di Indonesia menggunakan sistem ganda yang diwujudkan dengan program praktik industri dimana menganut konsep dual system dari Jerman. Menurut Zimmermann (2017), pendidikan dan pelatihan kejuruan ganda gaya Jerman yang disebut VET (Vocational Education and Training) telah diimplementasikan di negara-negara global 
selatan khususnya negara-negara berkembang. Sistem VET adalah contoh yang sangat baik karena dianggap sebagai rahasia sukses pendidikan di Jerman [3]. Penelitian terkait VET pernah dilakukan oleh Woods (2008) menunjukkan bahwa para pemuda di Australia sangat terbantu dalam masa transisi karena adanya VET memudahkan jalur mereka pasca lulus sekolah menuju dunia kerja [5].

Program praktik industri yang diterapkan di Indonesia bertujuan agar peserta didik memperoleh pengalaman langsung bekerja pada industri yang sebenarnya. Berdasarkan pedoman praktik kerja lapangan Depdikbud (2017:7) tujuan praktik industri yaitu: (1) memberikan pengalaman kerja langsung (real) untuk menanamkan (internalize) iklim kerja positif yang berorientasi pada peduli mutu proses dan hasil kerja, (2) menanamkan etos kerja yang tinggi bagi peserta didik untuk memasuki dunia kerja dan menghadapi tuntutan pasar kerja global, (3) memenuhi hal-hal yang belum dipenuhi di sekolah agar mencapai keutuhan standar kompetensi lulusan, dan (4) mengaktualisasikan penyelenggaraan model Pendidikan Sistem Ganda (PSG) antara SMK dan Institusi Pasangan (DUDI), memadukan secara sistematis dan sistemik program pendidikan di SMK dan program latihan di dunia kerja (DUDI) [6].

Pelaksanaan praktik kerja industri di SMK telah menghadapi berbagai persoalan. Menurut Agrawal (2013) dalam penelitiannya menjelaskan bahwa pada sebagian besar negara-negara maju dikawasan Asia seperti Afghanistan, Banglades, India dan Pakistan menunjukkan pendidikan kejuruan dan sistem pelatihan masih belum maksimal. Meskipun pemerintah di negara-negara ini telah membayar secara lebih dengan memperhatikan sektor ini dalam beberapa tahun terakhir, hasilnya masih kurang memuaskan [7]. Di Indonesia permasalahan yang terjadi yaitu: (1) Link and match belum berjalan efektif, (2) SMK kesulitan mencari mitra dunia usaha/industri, (3) Tidak ada dasar hukum yang mengikat agar dunia usaha/industri bermitra dengan SMK, (4) Dunia usaha/industri merasa direpotkan atau terganggu oleh kehadiran peserta didik/guru SMK, (5) Dunia usaha/industri khawatir mesin/alat rusak dan bahan praktik terbuang, (6) Link and match masih bersifat formalitas, jarang ditindaklanjuti, (7) Guru pembimbing dari industri belum memiliki keterampilan pedagogik, dan (8) Siswa prakerin/magang lambat beradaptasi dengan budaya kerja dunia usaha/industri [8]. Menghadapi persoalan yang ada perlu adanya evaluasi program terkait keterlakasanaan praktik industri.

Evaluasi merupakan hal yang sangat penting yang harus dilakukan didalam pelaksanaan suatu program. Sesuai pendapat Arikunto (2009:2) yang menyatakan bahwa evaluasi adalah suatu kegiatan untuk mengumpulkan informasi tentang bekerjanya sesuatu yang selanjutnya informasi tersebut digunakan untuk menentukan alternatif yang tepat dalam mengambil sebuah keputusan [10]. Secara umum evaluasi adalah suatu kegiatan atau tindakan yang sistematik dalam upaya menjaring dan menganalisis informasi atau data yang relevan dengan teknik tertentu untuk membuat suatu keputusan yang terkait dengan tingkat efektifitas, efisiensi, dan kemenarikan suatu program [11]. Adapun program adalah bagian dasar dari inisiatif strategis yang kompleks yang memiliki dampak dari efek keluaran yang dapat diamati sepanjang waktu oleh para pemangku kepentingan serta hasil dari perubahan spesifik dalam perilaku, pengetahuan, keterampilan, kondisi, dan tingkat kegiatan/operasi target suatu program [12]. Fungsi evaluasi di dalam pendidikan tidak dapat dilepaskan dari tujuan evaluasi itu sendiri, bahwa tujuan dari evaluasi program pendidikan ialah untuk mendapat data pembuktian yang akan menunjukkan sampai dimana tingkat kemampuan dan keberhasilan siswa dalam mencapai tujuan-tujuan kurikuler [14].

\begin{tabular}{|c|c|}
\hline $\begin{array}{l}\text { Level } 1 \\
\text { Reaction }\end{array}$ & Mengukur sejauh mana peserta bereaksi secara positif terhadap pembelajaran yang diperoleh \\
\hline $\begin{array}{l}\text { Level } 2 \\
\text { Learning }\end{array}$ & $\begin{array}{l}\text { Mengukur sejauh mana peserta memperoleh pengetahuan, keterampilan, dan sikap yang } \\
\text { dimaksud berdasarkan partisipasi mereka dalam proses pembelajaran }\end{array}$ \\
\hline $\begin{array}{l}\text { Level } 3 \\
\text { Behavior }\end{array}$ & $\begin{array}{l}\text { Mengukur sampai tingkat mana peserta menerapkan apa yang mereka pelajari selama pelatihan } \\
\text { ketika kembali beraktivitas semula }\end{array}$ \\
\hline $\begin{array}{c}\text { Level } 4 \\
\text { Result }\end{array}$ & $\begin{array}{l}\text { Mengukur sejauh mana hasil yang ditargetkan terjadi sebagai hasil dari peristiwa pembelajaran } \\
\text { dan penguatan selanjutnya }\end{array}$ \\
\hline
\end{tabular}

Sumber data : Kirkpatrick, D \& Kirkpatrick J. (2006)

Gambar 1.1 Model Kirkpatrick

Keterlaksanaan Program Praktik Industri Program Keahlian Teknik Pemesinan ........ 
Dalam pelaksanaan evaluasi program banyak sekali jenis dan cara yang dapat digunakan. Dalam penelitian ini menggunakan Model Evaluasi Kirkpatrick. Gambar 1.1 menunjukkan Model Evaluasi Kirkpatrick yang terdiri dari: reaksi, pembelajaran, perilaku, dan hasil. Pada level reaksi mengukur tingkat kepuasan peserta. Level kedua yaitu pembelajaran untuk mengukur tingkat pengetahuan, keterampilan serta perubahan sikap dan perilaku peserta pelatihan. Level ketiga yaitu perilaku berguna untuk mengetahui apakah program tersebut membawa perubahan pada iklim kerja. Level terakhir yaitu hasil berguna untuk mengkaji secara keseluruhan dampak dari program pelatihan yang dilaksanakan [15].

Berdasarkan pemaparan diatas, peneliti tertarik untuk melakukan penelitian pada salah satu SMK unggul yang ada di Kabupaten Malang yaitu SMK Muhammadiyah 1 Kepanjen. Sekolah ini merupakan salah satu SMK swasta yang menjadi rujukan sekolah lain yang merupakan bagian dari kebijakan pemerintah melalui Departemen Pendidikan dan Kebudayaan dalam mendirektortuk pusat pembinaan SMK sejak tahun 2015 [9]. SMK Muhammadiyah 1 Kepanjen juga merupakan salah satu SMK swasta di Kabupaten Malang yang memiliki program praktik kerja lapangan dengan berbagai permasalahan.

\section{METODE}

Penelitian ini bertujuan untuk mengetahui keterlaksanaan program praktik industri di SMK Muhammdiyah 1 Kepanjen. Jenis penelitian ini menggunakan metode evaluatif dengan pendekatan model kirkpatrick. Teknik pengumpulan data menggunakan angket, pre-test \& pos-test, dan dokumentasi. Subjek penelitian diambil menggunakan teknik purposive sampling sehingga diketahui jumlah siswa yang telah melaksanakan praktik industri berjumlah 60 siswa. Jumlah siswa tersebut digunakan untuk mengukur model Kirkpatrick level satu (reaction) dan dua (learning). Untuk level tiga (behavior) menggunakan subjek guru atau stakeholder sekolah yang memenuhi parameter sebagai berikut: (1) mengetahui kebijakan tentang program praktik industri, (2) mengetahui pelaksanaan kegiatan praktik industri, dan (3) terlibat langsung sebagai koordinator/penanggung jawab program praktik industri. Pada penelitian ini, untuk level empat (result) menggunakan metode dokumentasi berupa nilai yang telah diberikan oleh pihak industri kepada siswa.

Tabel 1. Proses Pengukuran Pengumpulan Data Evaluasi Praktik Industri

\begin{tabular}{|c|c|c|c|}
\hline No & Level evaluasi & Deskripsi & Metode pengambilan data \\
\hline 1. & Reaksi & $\begin{array}{l}\text { Mengukur tingkat kepuasan peserta } \\
\text { pelatihan terhadap program pelatihan } \\
\text { yang diikuti. }\end{array}$ & $\begin{array}{l}\text { Kuisioner (sampel siswa), dengan } \\
\text { skala pengukuran yaitu skala Likert. }\end{array}$ \\
\hline 2. & Pembelajaran & $\begin{array}{l}\text { Mengukur tingkat pembelajaran yang } \\
\text { dialami peserta didik }\end{array}$ & Pre-test \& post-test \\
\hline 3. & Perilaku & $\begin{array}{l}\text { Mengukur implementasi hasil dari } \\
\text { praktik industri }\end{array}$ & $\begin{array}{l}\text { Kuisioner (sampel guru), skala } \\
\text { Likert }\end{array}$ \\
\hline 4. & Hasil & $\begin{array}{l}\text { Mengukur keberhasilan praktik industri } \\
\text { secara keseluruhan individu yang } \\
\text { disebabkan adanya peningkatan }\end{array}$ & $\begin{array}{l}\text { Dokumentasi (data nilai hasil } \\
\text { praktik industri siswa) }\end{array}$ \\
\hline
\end{tabular}

Tabel 1 menunjukkan empat aspek mengenai instrumen yang akan digunakan untuk penelitian. Pada aspek satu (reaksi peserta didik) dan aspek tiga (perubahan perilaku peserta didik) menggunakan metode angket, sedangkan untuk aspek dua (pembelajaran) menggunakan pre-test dan post-test dan aspek empat (hasil) menggunakan metode dokumentasi.

\section{HASIL}

Tabel 2 Hasil Analisis Data Level Reaction

\begin{tabular}{lcl}
\hline Aspek Reaksi & Persentase rata-rata & Kategori \\
\hline Fasilitas & $71 \%$ & Baik \\
Materi yang diberikan & $79 \%$ & Sangat Baik \\
Instruktur lapangan & $79 \%$ & Sangat Baik \\
Waktu praktik industri & $74 \%$ & Baik \\
Sarana dan prasarana & $80 \%$ & Sangat baik \\
\hline
\end{tabular}

Hasil penelitian angket level reaksi siwa pada Tabel 2 meliputi aspek fasilitas, materi, instruktur lapangan, waktu, dan sarana prasarana. 
Tabel 3 Hasil Pengolahan Data Level Learning Secara Deskriptif

\begin{tabular}{ccccc}
\hline & Mean & N & Std. Deviation & Std. Error Mean \\
\hline Nilai Pre-test & 62,82 & 60 & 15,06 & 1,94 \\
Nilai Post-test & 81,68 & 60 & 7,56 & 0,98 \\
\hline
\end{tabular}

Pada Tabel 3 nilai rata-rata hasil pre-test < post-test, maka itu artinya secara deskriptif ada perbedaan atau peningkatan rata-rata hasil belajar antara pre-test dengan hasil post-test.

Tabel 4 Hasil Pengolahan Data Level Learning Menggunakan Paired Sample t-Test

\begin{tabular}{cccc}
\hline & Correlation & Mean & $p$-value \\
\hline Nilai Pre-test \& Nilai Post-test & 1,00 & $-18,87$ & 0,00 \\
\hline
\end{tabular}

Pada Tabel 4 hasil uji paired sample t-test menunjukkan bahwa nilai correlation sebesar 1,00 artinya terdapat hubungan yang sangat kuat dan positif antara kedua data atau hubungan variabel pre-test dengan variable pots-test. Hasil diatas juga menunjukkan nilai p-value yaitu 0,00 (p-value $<0,05$ ), maka dapat dikatakan bahwa terdapat perbedaan antara nilai pre-test dan post-test. Nilai mean menunjukkan $-18,87$ atau bernilai negatif artinya terjadi kecenderungan kenaikan nilai sesudah adanya praktik industri

Tabel 5 Hasil Analisis Data Level Behavior

\begin{tabular}{ccc}
\hline Aspek Perubahan Perilaku & Persentase rata-rata & Kategori \\
\hline Kecakapan komunikasi & $75 \%$ & Baik \\
Keterampilan intelektual & $79 \%$ & Sangat Baik \\
Strategi kognitif & $82 \%$ & Sangat Baik \\
Keterampilan motorik & $78 \%$ & Sangat Baik \\
Sikap siswa & $75 \%$ & Baik \\
\hline
\end{tabular}

Hasil penelitian angket pada Tabel 5 menjabarkan persepsi guru terhadap perubahan perilaku siwa meliputi aspek kecakapan komunikasi, intelektual, strategi kognitif, motorik dan sikap siswa.

Tabel 6 Hasil Analisis Data Level Result

\begin{tabular}{cccccc}
\hline & N & Minimum & Maximum & Mean & Std. Deviation \\
\hline Nilai PI & 30 & 77,89 & 90,67 & 83,0660 & 2,67432 \\
\hline
\end{tabular}

Hasil pengolahan data pada Tabel 6 diperoleh dari nilai yang diberikan pihak industri pada siswa mencakup nilai kompetensi dan nilai sikap siswa selama mengikuti program praktik industri.

\section{PEMBAHASAN}

\section{Aspek Reaksi}

Hasil penelitian aspek reaksi siswa dalam kategori baik, hal ini dibuktikan dengan rata-rata reaksi siswa yang menyatakan setuju pada pelayanan sekolah dan industri. Kualitas proses atau pelaksanaan suatu pelatihan dapat diukur melalui tingkat kepuasan pesertanya, hasil keduanya selalu berbanding lurus [16]. Sejalan dengan penelitian Iskandar (2018) hasil penelitian level reaksi peserta pelatihan dimana terdapat lima sub-indikator dinyatakan sangat puas [17].

\section{Fasilitas}

Reaksi siswa pada fasilitas program praktik industri sebagian besar menyatakan setuju. Hal ini dibuktikan dengan ratarata persentase sebesar $71 \%$ mencakup pemilihan tempat praktik industri, pembekalan sebelum praktik industri, pengarahan 
praktik kerja industri, dan pengawasan tentang kondisi di industri sudah sesuai. Siswa akan memiliki minat, perhatian, dan motivasi belajar yang lebih baik ketika mereka bereaksi positif terhadap lingkungan belajar atau fasilitas yang diterima [18].

Sesuai temuan penelitian Mefinal (2017:74) siswa oleh sekolah diberikan kelonggaran untuk memilih tempat praktik industri. Selain itu, adanya peran dari sekolah dalam membekali peserta didik dengan cara memberikan sosialisasi yang diberikan oleh guru produktif atau guru pembimbing, dan dilakukan pengawasan oleh guru pembimbing setiap 1 bulan sekali dengan cara mengunjungi tempat industri untuk mengetahui perkembangan peserta didik [19].

\section{Materi}

Hasil penelitian menunjukkan bahwa pada indikator materi sebagian besar siswa sangat setuju dengan tugas pekerjaan yang diberikan. Dalam praktiknya siswa mendapat kesempatan mengoperasikan mesin-mesin yang ada di industri. Selain itu kemampuan yang sudah dimiliki peserta didik melalui latihan dan praktik di sekolah juga di implementasikan secara nyata sebagai upaya penerapan kompetensi ke dalam dunia kerja [20]. Data diatas didukung oleh penelitian Syahroni (2014) yang menyatakan bahwa pelaksanaan praktik kerja industri merupakan implementasi dari teori/materi yang diperoleh di sekolah, hal ini dapat terlihat dari $79 \%$ siswa yang menyatakan bahwa praktik kerja industri bermanfaat dalam kesesuaian materi terhadap relevansi pengetahuan [21].

\section{nstruktur Lapangan}

Reaksi siswa terhadap instruktur lapangan mendapat respon sangat setuju. Hasil penelitian rata-rata persentase sebesar 79\% yang menunjukkan sebagian besar instruktur lapangan telah melakukan prosedur dengan baik, hal ini sebagai upaya partisipasi DU/DI untuk mensukseskan progam praktik industri. Menurut pendapat Sunardi (2016:2) instruktur lapangan merupakan salah satu instrumental yang paling dominan, profesional dan memiliki wawasan mendalam tentang dunia kerja, baik dunia usaha maupun dunia industri [22].

Data diatas didukung oleh penelitian Darwis (2016) bahwa dalam proses pembimbingan diketahui sebagian besar responden menyatakan persepsi yang baik terhadap pelaksanaan praktik kerja lapangan di SMK Muhammadiyah 1 Kepanjen. Hal ini disebabkan karena industri dapat menerima dengan baik peserta praktik industri. Instruktur lapangan juga memberikan pengenalan lingkungan industri dan proses pembimbingan untuk mengkondisikan dan mengawasi peserta praktik industri [23].

\section{Waktu Praktik Industri}

Hasil penelitian indikator waktu praktik industri menunjukkan sebagian besar siswa menyatakan setuju mengenai jadwal praktik industri. Hal ini dibuktikan dengan rata-rata persentase sebesar $75 \%$ mencakup melaksanakan praktik industri selama 3 bulan penuh, pelaksanaan jam kerja selama 8 jam, akan tetapi kebanyakan industri tidak mewajibkan lembur bagi siswa serta mengharuskan izin saat absen selama praktik industri.

Pelaksanaan praktik industri di beberapa negara eropa dilakukan dalam waktu yang sangat lama karena dianggap sangat penting bagi siswa. Melalui praktik industri siswa memiliki kesempatan untuk mengeksplorasi dan menerapkan teori yang dipelajari [24]. Selaras dengan penelitian Aminah (2015) sebesar 70,98\% responden setuju dengan jadwal pelatihan yang ada. Namun, belum sangat memuaskan, hal ini terkait dari sisa jumlah persentase sebagian kecil masih ada yang menjawab kurang puas [25].

\section{Sarana dan Prasarana}

Hasil indikator sarana dan prasarana sebagian besar peserta didik menjawab setuju. Hal ini bahwa dibuktikan dengan rata-rata persentase sebesar $80 \%$ yang menunjukkan bahwa industri yang ditempati siswa memiliki mesin-mesin yang sesuai dengan apa yang di butuhkan, serta siswa diberikan alat pelidung diri (APD) selama praktik industri. Menurut Cox (2006) kualitas suatu program tergantung pada sarana dan prasarana yang melibatkan peserta didik [26]. Senada dengan penelitian Nidhom (2015:11) menunjukkan bahwa kemampuan peserta didik yang berkaitan dengan kompetensi keahliannya akan meningkat secara drastis karena DU/DI memiliki peralatan canggih, serta untuk mendapatkan informasi perkembangan teknologi yang belum diperoleh di sekolah [27].

\section{Aspek Pembelajaran}

Hasil penelitian secara keseluruhan dari rata-rata nilai yang diperoleh hasil pre-test siswa menunjukkan angka 62,82 dan setelah melakukan praktik industri hasil post-test berada pada angka rata-rata 81,68. Karena nilai rata-rata hasil pre-test < post-test, maka itu artinya secara deskriptif ada perbedaan atau peningkatan rata-rata hasil belajar antara pre-test dengan hasil post-test. Hasil uji paired sample t-test untuk membuktikan nilai signifikan menunjukkan nilai p-value yaitu 0,00 (p-value < $0,05)$, maka dapat dikatakan bahwa terdapat perbedaan antara nilai pre-test dan post-tes. 
Kenaikan nilai dalam pelaksanaan pelaksanaan praktik kerja industri tersebut dimungkinkan adanya motivasi belajar siswa selama praktik industri sebagai bekal di masa mendatang [28]. Hal ini sejalan dengan penelitian Chatterjee, Yadav, Ananad, Malik, Kotwal, dan Kunte (2018) yang menunjukkan bahwa peningkatan pengetahuan siswa melalui pre-test dan posttest dilandasi adanya kebutuhan untuk menghadiri lokakarya sebagai wadah untuk menambah wawasan dalam menghadapi tantangan di masa depan [29]. Adanya peningkatan pengetahuan yang cukup tinggi setelah pelaksanaan praktik industri kemungkinan juga dapat mempengaruhi keterampilan dari siswa tersebut [30].

\section{Aspek perubahan perilaku}

\section{Kecakapan Komunikasi}

Hasil dari penelitian menunjukkan bahwa kecakapan komunikasi siswa progam keahlian teknik pemesinan di SMK Muhammadiyah 1 Kepanjen sangat baik. Hal tersebut ditinjau dari hasil rata-rata persentase sebesar $75 \%$. Kemampuan Komunikasi menurut Wicaksono (2013:60) adalah sikap untuk melakukan suatu proses pengiriman pesan dari seseorang kepada orang lain atau beberapa orang, baik verbal maupun non verbal yang di tanggapi oleh orang lain dan merupakan interaksi antara pribadi-pribadi yang terlibat secara utuh dan langsung satu sama lain dalam menyampaikan dan menerima pesan secara nyata [31]. Data diatas didukung oleh penelitian Suranto, Widiarti, \& Hastasari (2019) yang menyatakan sebagian besar siswa mengaku setelah mengikuti pelatihan lebih cakap dalam berkomunikasi selain itu dapat meningkatkan kepercayaan diri untuk tampil di depan umum[32].

\section{Keterampilan Intelektual Siswa}

Hasil dari penelitian menunjukkan bahwa keterampilan intelektual siswa sangat baik. Hal tersebut dibuktikan rata-rata persentase sebesar 79\% mencakup kegiatan siswa dalam melakukan pengamatan, menyusun kerangka berfikir, mengintepretasikan penjelasan materi, menjabarkan ide umum ke dalam ide yang spesifik, dan memberikan persepsi yang cermat melalui berbagai sudut pandang.

Keterampilan intelektual erat hubunganya dengan berpikir kritis yaitu kegiatan yang dilakukan berfikir secara intelektual untuk menganalisis, membuat pertimbangan, dan mengambil keputusan secara tepat dan melaksanakannya secara benar [33]. Sejalan dengan penelitian Lia, Syamwil, Widyani (2017 ) menyatakan penilaian keterampilan siswa sebelum pelaksanaan pembelajaran diasumsikan pada nilai 1,00 yang berarti dalam kriteria kurang, sedangkan nilai keterampilan siswa setelah kegiatan pembelajaran adalah 3,59, hal ini menandakan adanya peningkatan keterampilan siswa [34].

\section{Strategi Kognitif}

Hasil dari penelitian menunjukkan bahwa strategi kognitif siswa masuk dalam kategori sangat baik. Dibuktikan dengan rata-rata nilai persentase sebesar $82 \%$ mencakup kemampuan siswa dalam menyelesaikan permasalahan yang dihadapi dengan proses-proses berpikir terstruktur tentang materi yang dipelajari. Fatimah (2016) menjelaskan bahwa strategi kognitif siswa ialah suatu kondisi dimana peserta didik menemui pengalaman baru yang tidak tertata rapi dalam struktur kognitifnya, maka kemudian peserta didik akan menerima konsep baru, yang dipahami dan dapat dipercaya untuk dipergunakan pada situasi lain [35]. Penelitian Spacy (2014) menguatkan data diatas bahwa strategi kognitif siswa dapat meningkatkan keterampilan siswa dengan menyediakan tempat belajar siswa untuk berkembang dalam menambah literasi belajar dan pemahaman konten sesuai bidang yang dipelajari [36].

\section{Keterampilan Motorik}

Hasil dari penelitian menunjukkan bahwa keterampilan motorik siswa masuk dalam kategori sangat baik. Ditinjau dari hasil rata-rata nilai persentase sebesar $78 \%$ mengenai keaktifan siswa dalam menyampaikan gagasan untuk menyelesaikan masalah dalam kelompok, kemampuan menerima ide dari sudut pandang teman sejawat, dan berperan aktif dalam kerja kelompok. Zunanda (2015) menyatakan bahwa kemampuan motorik adalah suatu kemampuan yang dapat diperoleh dari keterampilan gerak umum (praktek) yang berkaitan dengan pelaksanaan dan peragaan suatu keterampilan yang dipelajari [37]. Sejalan dengan penelitian Prett, Melissa, Peterson (2015) keterampilan motorik siswa dapat membantu siswa untuk berpartisipasi lebih dalam proses pembelajaran dan berperan penting untuk menentukan kekuatan serta keterbatasan siswa dalam perkembangan belajarnya [38].

\section{Sikap Siswa}

Hasil dari penelitian menunjukkan bahwa sikap siswa program keahlian teknik pemesinan di SMK Muhammadiyah 1 Kepanjen baik. Hal tersebut ditinjau dari rata-rata nilai persentase sebesar $75 \%$ yang diperoleh berdasarkan indikator sikap siswa mengenai kemampuan perilaku berkonsentrasi siswa dengan rentang waktu yang cukup lama. 
Bahri (2015) menyatakan dalam belajar diperlukan konsentrasi untuk mewujudkan perhatian terpusat. Oleh karena itu, setiap pelajar atau mahasiswa berusaha dengan keras agar mempunyai konsentrasi tinggi dalam belajar, sikap hati-hati saat dituntut untuk segera selesai dalam menyelesaikan pekerjaan, dan kegiatan melakukan pengecekan ulang dalam setiap pekerjaan [39]. Temuan penelitian serupa oleh Foong (2015) menjelaskan bahwa sikap dan lingkungan belajar siswa mempunyai hubungan yang mempengaruhi niat dan tingkat pengetahuan siswa dalam proses belajar [40].

\section{Aspek Hasil}

Penelitian pada level result bertujuan untuk mengetahui dampak jangka pendek yang didapat siswa setelah melakukan praktik industri. Hasilnya secara keseluruhan dari rata-rata nilai praktik industri yang diperoleh dengan jumlah 60 siswa secara minimum menunjukkan angka 77,89 dan nilai maksimum yaitu 90,67, dengan demikian nilai yang diperoleh telah mencapai KKM sebesar 75. Hasil tersebut menunjukkan aspek pada level result sudah baik. Hasil akhir yang sesuai dengan tujuan program sebagai akibat peserta mengikuti pelatihan dapat digunakan sebagai salah satu acuan ketercapaian suatu program (Meghe \& Muley, 2013). Sejalan dengan temuan penelitian Syarifah (2013) evaluasi hasil belajar praktik industri pada kompetensi keahlian teknik pemesinan meliputi (1) penilaian terhadap hasil kerja, (2) penilaian yang dilakukan oleh industri, dan (3) penilaian oleh sekolah dengan laporan jurnal harian selama melaksanakan praktik industri [41].

\section{PENUTUP}

Keterlaksanaan program praktek industri program keahlian teknik pemesinan di SMK Muhammadiyah 1 Kepanjen yang menggunakan evaluasi model Kirkpatrick adalah sebagai berikut: (1) Keterlaksanaan program praktik industri pada level reaction menunjukkan penilaian siswa pada sekolah (fasilitas yang diberikan) untuk persiapan pelaksanaan praktik industri dalam kategori baik dan penilaian siswa pada dunia industri (materi yang diberikan, instruktur lapangan, jadwal praktik industri, dan sarana prasarana) yang dilakukan pada proses pelaksanaan praktik industri dalam kategori baik, (2) Keterlaksanaan program praktik industri pada level learning secara garis besar memberikan dampak positif dalam proses belajar peserta didik setelah melaksanakan praktik industri terutama pada aspek pengetahuan, (3) Keterlaksanaan program praktik industri pada level behavior yang menunjukkan penilaian guru terhadap perubahan perilaku belajar siswa pada aspek kecakapan komunikasi, keterampilan intelektual, strategi kognitif, keterampilan motorik dan perubahan sikap siswa dalam kategori sangat baik, dan (4) Keterlaksanaan program praktik industri pada level result memberikan dampak yang signifikan pada pengalaman belajar siswa tentang wawasan kejuruan teknik pemesinan yang belum di dapat di sekolah sebagai bekal menjadi lulusan yang terampil dan siap bekerja.

\section{DAFTAR RUJUKAN}

Agrawal, T. 2013. Vocational Education and Training Program (VET): an Asian Perspective. Asia-Pacific Journal of Cooperative Education, 14(1): 15-26. [7]

Arikunto, S. \& Jabar. 2009. Evaluasi Program Pendidikan. Jakarta: Bumi Aksara. [10]

Akturuzzaman, \& Clement. 2011. Vocational Education and Training (VET) in Human Resource Development: A Case Study of Bangladesh. Academic Research Journal Internasional. 1 (7). 266-275. [4]

Aminah, H. 2015. Model Evaluasi Kirkpatrick dan Aplikasinya dalam Pelaksanaan Pelatihan (Level Reaksi dan Pembelajaran) di Pusat Pendidikan dan Pelatihan Perum Jakarta. Jurnal Riset Manajemen Sains Indonesia. 6 (1). 376-394. [25]

Bates, R. 2004. A critical analysis of evaluation practice: the Kirkpatrick model and the principle of beneficence. Journal Evaluation and Program Planning .27 341-347. [18]

Cox, J 2006. The Quality of an Instructional Program. National Education Association Alaska. http//www.ak.nea.org./excellence/coxquality. Diakses 20 Oktober 2019. [26]

Chatterjee, K., Yadav, A., Ananad, N., Malik, A., Kotwal, A \& Kunte R. 2018. Use of Kirkpatrick's Model for Evaluation of Reaction and Learning of Participant of National Level Workshop on Linear Regression. International Journal of Community Medicine and Public Health. 5 (11). 4909-4011. [29]

Depdikbud. 2017. Pedoman Praktik Kerja Lapangan. Jakarta. Depdikbud. [6] 
Fatimah, N., Gunawan., \& Wahyudi. 2016. Pembelajaran Berbasis Masalah dengan Strategi Konflik Kognitif Terhadap Penguasaan Konsep dan Kemampuan Berpikir Kritis Fisika Siswa Kelas XI SMKN 1 Lingsar Tahun Pelajaran 2015/2016. Jurnal Pendidikan Fisika dan Teknologi. 2 (4). [36]

Foong, Y \& Khoo, H. 2015. Attitude, Learning Environment and Current Knowledge Enhancement of Accounting Students in Malaysia. Journal of Accounting in Emerging Economies. 5 (1). 202-221. [40]

Irawan, V.T. 2017. Blended Learning Based on Schoology: Effort of Improvement Learning Outcome and Practicum Chance in Vocational High School. Curriculum \& Teaching Studies | Research Article. 4 (1282031). [24]

Juliyanti. 2013. Peran DUDI dalam Implementasi Pendidikan Sistem Ganda di SMKN I Salatiga. Tahun 2013/2014. Tesis Tidak Diterbitkan. Salatiga: Program Pasca Sarjana Universitas Kristen Satya Wacana. [8]

Kirkpatrick, D.L. \& KirkPatrick J.D. 2006. Evaluating Training Program the Four Levels. San Francisco: Berret Kohler Publisher, Inc. [15]

Kotler, P. 2003. The Art of Building Cutomer Value. Jakarta: LPMB [14]

Lia, N., Syamwil R, \& Widayani, S. 2017. Model Pembelajaran Keterampilan Vokasional Berbasis Potensi Lokal di SMA Wilayah Kalimantan. Journal of Vocational and Career Education. 2 (2). 50-58. [34]

Linzalone, R \& Schiuma, G. 2015. A Review of Program and Project Evaluation Models Measuring Business. Business Journal and Management. 19 (3). 90 - 99. [12]

Mefinal, D.A. 2017. Studi Pelaksanaan Praktik Kerja Industri untuk Mempersiapkan Tenaga Terampil di SMK Muhammadiyah 1 Kepanjen. Tahun 2016/2017. Skripsi tidak Diterbitkan. Malang: Fakultas Teknik Universitas Negeri Malang. [19]

Meghe, B \& Muley, A. 2013. Evaluation of Training and Development Practices of CTPS Using Kirkpatrick Method: A Case Study. International Journal of Application or Innovation Engineering \& Management, ISSN 2319-4847. [23]

Mukhadis, A. 2016. Metodologi Penelitian Kuantitatif: Bidang Pendidikan dan Contoh Aplikasinya. Malang: Aditya Media Publishing. [11]

Pamekas, R. 2016. Pelaksanaan Praktik Kerja Industri Peserta Didik Kelas XI Kompetensi Keahlian Administrasi Perkantoran SMK Bopkri 1 Yogyakarta. Tahun 2016/2017. Skripsi Tidak Diterbitkan. Yogyakarta: Program Studi Pendidikan Administrasi Universitas Negeri Yogyakarta. [28]

Putera, A.D. 2018. Pengangguran Berkurang 14000 Orang dalam Setahun Terakhir. (https://ekonomi.kompas.com/read/2018/05/07/173131526/bps-pengangguran-berkurang-140000- orang-dalamsetahun-terakhir). Diakses 1 Oktober 2018[1]

Pratt, B \& Peterson, M. 2015. The Role of Physical Therapists in Advancing Special Education. Journal Interdisciplinary Connections to Special Education. 47-66[38]

Silberman, Melvin L. (2006). Active Training: AHandbook of Technique, Designs, Case Examples, and Tips. San Fransisco: Pfeiffer an Inprint of Wiley. [16]

Spacy. 2014. Models of Learning and Literacy Development. Journal education RMIT University, 4. 31-45. [36]

Sukardi. 2014. Evaluasi Program Pendidikan dan Kepelatihan. Jakarta: Bumi Aksara. [13]

Sukoco. 2015. SMK Muhammadiyah 1 Kepanjen Jadi SMK Rujukan Tahun ini Siap Membina 10-16 SMK Sekitarnya. (Online) (http://www.smkm1kpn.sch.id). Diakses 1 Oktober 2018. [9]

Sunardi \& Sudjimat, D.A. 2016. Magang Industri untuk Meningkatkan Relevansi Kompetensi Profesional Guru Produktif SMK. Jurnal Teknologi dan Kejuruan. 39 (2). 171-182. [22]

Syahroni, A. 2014. Persepsi Siswa Terhadap Manfaat Pelaksanaan Praktek Kerja Industri di SMKN 1 Lembah Gumanti. Jurnal Administrasi Pendidikan, 2 (1). 275-831. [21] 
Syarifah, N. 2013, Analisis Praktik Kerja Industri Ditinjau dari Peningkatan Kompetensi Siswa SMK. Tahun 2013/2014. Tesis Tidak Diterbitkan. Bandung: Program Pasca Sarjana Universitas Pendidikan Indonesia. [42]

Wicaksono, G. 2013. Penerapan Teknik Bermain Peran dalam Bimbingan Kelompok untuk Meningkatkan Kemampuan Komunikasi Interpersonal Siswa Kelas X Multimedia SMK IKIP Surabaya. Jurnal Mahasiswa Bimbingan Konseling. 1 (1). 61-78. [31]

Woods, D. 2008. The impact of VET on Transition to Work for Young People in Australia. Journal Vocational Education. 50 (6). 465-473. [5]

Yoto. 2016. Model Alternatif Pengembangan SMK di Indonesia (Upaya Penyiapan Tenaga Kerja Terampil di Industri). Paper pada Seminar Nasional Pendidikan Kejuruan "Tantangan Pendidikan Kejuruan Abad XXI" tahun 2016 di Universitas Negeri Malang, Tanggal 24 September 2016. [2]

Zimmermann, N. 2017. Germany Exports A Secret Of Its Success: Vocational Education, DW (Deutsche Welle). Dari (http:// www.dw.com/en/germany-exports-a-secret-of- its-success-vocational-education/a-38114840) diakses pada 10 juli 2019. [3]

Zunanda, M \& Sinulingga, K. 2015. Pengaruh Model Pembelajaran Berbasis Masalah dan Kemampuan Berpikir Kritis Terhadap Keterampilan Pemecahan Masalah Fisika Siswa SMK. Jurnal Pendidikan Fisika dan Teknologi. 4(1). [37] 